\title{
Indigenous Trichoderma harzianum as Biocontrol toward Blight Late Disease and Biomodulator in Potato Plant Productivity
}

\author{
Susiana Purwantisari ${ }^{1 *}$, Harum Sitepu ${ }^{2}$, Isworo Rukmi ${ }^{1}$, Arina Tri Lunggani ${ }^{1}$, \\ Kadarwati Budihardjo ${ }^{3}$ \\ ${ }^{1}$ Biology Department, Faculty of Sciences and Mathematic, Universitas Diponegoro, Indonesia \\ ${ }^{2}$ Agribusiness Department, Sekolah Tinggi Ilmu Pertanian Farming Semarang, Indonesia \\ ${ }^{3}$ Institut Pertanian Stiper Jogjakarta, Indonesia \\ *Corresponding Author: susiana_purwantisari@yahoo.co.id
}

Submitted: 2020-10-16. Revised: 2020-12-01. Accepted: 2021-02-28

\begin{abstract}
Indigenous Trichoderma has widely used in late-blight epidemic areas in Magelang, Indonesia as biocontrol and biomodulator. But it application still lacks of scientific proof, even though it is potently to be developed. Therefore, this study aims to identify and evaluate indigenous Trichoderma application in eradicating late blight and increase productivity. This research was an experimental posttest-only using six experimental plots, with P0 plot with no treatment. The solution was made by dissolve indigenous Trichoderma solid-starter into water $(\mathrm{m} / \mathrm{v})$, then used for treatment. The treatment plots including: two groups of sprayed-only plots with doses of $100 \mathrm{~g} / 10 \mathrm{~L}$ of solution for P1 and $150 \mathrm{~g} / 10 \mathrm{~L}$ of solution for P2; and two group treated with sprayed-poured method using doses of $100 \mathrm{~g} / 10 \mathrm{~L}$ of solution for P3 and $150 \mathrm{~g} / 10 \mathrm{~L}$ of solution for P4. The positive control group was P5 group, treated using chemical pesticides and tuber booster. The microscopic identification revealed that the local bioagent was Trichoderma harzianum species. Application of T. harzianum in $\mathrm{P} 4$ was significantly increased the productivity. However, it was not effective in increasing growth, but able to reduce the intensity of late blight disease. The research revealed that native Trichoderma is able to be used as antiinfectious agent and potentially improve the quality of potato plants. In the future, this research may worthwhile for farmers to develop and produce trustworthy and proven Trichoderma-based biocontrol and help them increase the potato production economically.
\end{abstract}

Key words: late blight; potato; organic fungicide; Phytophthora infestans; Trichoderma harzianum

How to Cite: Purwantisari, S., Sitepu, H., Rukmi, I., Lunggani, A. T., \& Budihardjo, K. (2021). Indigenous Trichoderma harzianum as Biocontrol toward Blight Late Disease and Biomodulator in Potato Plant Productivity. Biosaintifika: Journal of Biology \& Biology Education, 13(1), 26-33.

DOI: http://dx.doi.org/10.15294/biosaintifika.v13i1.26706

\section{INTRODUCTION}

In Indonesia, food diversification program has recommended potatoes as an alternative food substitute for rice (Kholifah \& Mustanir, 2019), this is because potatoes contain high amount of carbohydrates, protein, fat and vitamin $\mathrm{C}$ (Beals, 2019). Potato production in Indonesia is spread across 18 provinces, with total production reaching 1.3 million tons in 2019, and Central Java itself contributes $22.36 \%$ of total national production or the largest supplier of potatoes after East Java in 2019. The area of potato plantations in Central Java continued to increase by up to $5.60 \%$ (BPS, 2019b), while the productivity increased by 9.11 from 2017 to 2019 (BPS, 2019a).

Potato demand currently increases as an effect of growth population and changes in consumption life style (Rachman \& Napitupulu, 2018). However, potato productivity is often threatened due to the emergence of late blight caused by the pathogenic fungus Phytophthora infestans (Mönt.) De Bary, especially during the rainy season. (Subhani, 2016). Late blight has become endemic to potato crop centers in the plateaus because of high humidity and low temperatures support conidia to germinate. $P$. infestans infection results in crop damage that begins with leaf wilt, then ended up with decreases potato productivity (Bairwa et al., 2016; Schepers et al., 2016).

The uncontrolled use of fungicide doses and application may trigger an emergence of fungicideresistant $P$. infestans, and even more pathogenic that potentially spread out by emergence of heterothallic traits (Leesutthiphonchai et al., 2018; Majeed et al., 2017). It leads potato farmers to apply higher doses of fungicides to kill $P$. infestans. However, it can damage the microhabitat around potato plant and kill mutualistic fungi for potato crops. In other way, the farmers will use more chemical product, mainly increasing the doses of chemical fertilizers to increase their crop productivity. Even though, high doses and long-term usage of chemical fertilizers causes a loss of soil $\mathrm{pH}$ balance which results in scarcity of certain minerals (Zubrod et al., 2017). The chemical pesticides also cause a decrease in land productivity due to the loss of soil fertilizing organisms (Mahmood et al., 2016), blooming water and kills 
aquatic organisms (Hasenbein et al., 2016), and threated human health (Kim et al., 2017).

The community groups in potato-producing centers are used to apply indigenous antagonistic agent as biocontrol as well as biomodulator to prevent late blight while increasing potato productivity. The agents is well developed by the Pest and Disease Observation Laboratory of Kedu, Temanggung District. The advantages of indigenous Trichoderma sp. isolates are adaptable to the natural conditions and not an invasive species (Purwantisari et al., 2018b). However, the effectiveness of indigenous Trichoderma sp. as biocontrol and biomodulator for potatoes growth needs to be evaluated for its stability and effectiveness if it used in other areas. Therefore, this study aimed to identify and evaluate indigenous Trichoderma performance in eradicating late blight and increase the plant productivity. This research may help farmer more confident to develop Trichodermabased biocontrol as a biocontrol and biomodulator to enhance potato productivity.

\section{METHODS}

This research was a true experimental posttestonly control group design with a limited-field test model in the late blight endemic plantation Pakis Village, Magelang District at altitude of $1280 \mathrm{~m}$ a.s.l. The certified Granola (G1) was planted in farmer's field with typically latosol soil type, $\mathrm{pH} 6.5$.

\section{Local Biocontrol fungus Trichoderma sp. identification}

Identification of local biocontrol products was carried out using stock cultures from local Trichoderma sp. isolate, developed by the Pest and Disease Observation Laboratory of Kedu, Temanggung District. The Trichoderma sp. was cultured from stock then inoculated on the potato dextrose agar (PDA) media in petri dish, then incubated in an incubator for 5 to 7 days at $20-25^{\circ} \mathrm{C}$. Characterization of Trichoderma sp. was described based on the macroscopic and microscopic mold morphology. The results of observations obtained were characterized using the books from Samson et al. (2019) and Robinson (2011).

\section{Setting up for potato planting}

The tiling process was carried by fertilizing the soil with combination of chicken manure and NPK Phonska that were mixed using a hoe, a week before planting. The doses of fertilizer in the tiling process was equal to $1.25 \mathrm{~kg}$ of chicken manure per hole and 50 gr of NPK Phonska per hole. The holes distance was arranged every $50 \mathrm{~cm}$ between rows and $60 \mathrm{~cm}$ within row (Figure 1).

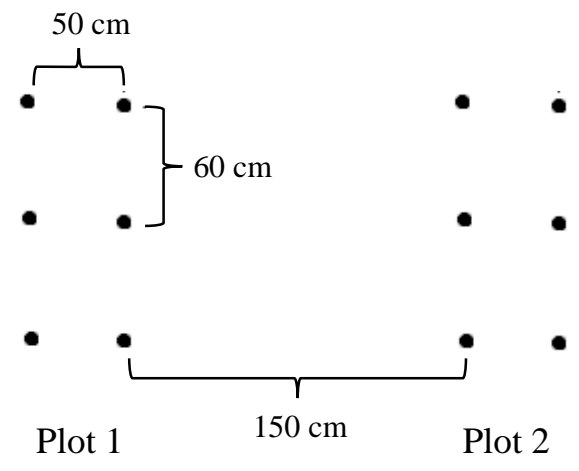

Figure 1. Potato planting distances between and among plots. Black spot representing places for planting the potato seed

This study used six treatment plots, which every plot contained 30 holes for planting the potato seeds. The plots included; P0 as negative control (without any treatment), then the treatment groups was treated using diluted native Trichoderma sp. starter in sterile fresh-water. The treatment plots consisted of sprayedonly plots with doses of $100 \mathrm{~g} / 10 \mathrm{~L}$ of solution for $\mathrm{P} 1$ and $150 \mathrm{~g} / 10 \mathrm{~L}$ for P2; sprayed-poured plots with doses of $100 \mathrm{~g} / 10 \mathrm{~L}$ of solution for P3 and $150 \mathrm{~g} / 10$ $\mathrm{L}$ of solution for P4. The positive control plot or P5 was intervened using chemical pesticides and tuber booster.

\section{Potato plant maintenance}

The potato plant was maintained by applying fungicides and insecticides from day $15^{\text {th }}$ until day $35^{\text {th }}$, as an early treatment. The given fungicide consisted of $2 \mathrm{~g} / \mathrm{L}$ of mancozeb $80 \%$ active compound, then the insecticide consisted of $30 \mathrm{~g} / \mathrm{L}$ of emamectin benzoate and $0.5 \mathrm{cc} / \mathrm{L}$ of lufenuron (the brand was covered for ethic reason). The early treatment was carried out repeatedly every 10 days for three times (age 15 days, 25 days, and 35 days). In addition, after day $35^{\text {th }}$, as much as $2 \mathrm{~g} / \mathrm{L}$ of a tuber stimulant or booster was applicated every once a week. This tuber stimulant was applied by spraying at day $35^{\text {th }}$ until day $60^{\text {th }}$ after planting, once a week. The Trichoderma sp. treatment as a biocontrol agent in treating potato blight and biomodulator of the plant production was carried out after day $35^{\text {th }}$ (Table 1 ). 
Table 1. The periodic treatment of Trichoderma sp. application.

\begin{tabular}{cl}
\hline Treatment & Period \\
\hline P0 & No treatment \\
P1 & at $\mathrm{H}+42, \mathrm{H}+47, \mathrm{H}+51, \mathrm{H}+53, \mathrm{H}+55, \mathrm{H}+57, \mathrm{H}+59 ;$ \\
P2 & at $\mathrm{H}+42, \mathrm{H}+47, \mathrm{H}+51, \mathrm{H}+53, \mathrm{H}+55, \mathrm{H}+57, \mathrm{H}+59 ;$ \\
P3 & at $\mathrm{H}+53, \mathrm{H}+55, \mathrm{H}+57, \mathrm{H}+59, \mathrm{H}+61 \mathrm{dan} \mathrm{H}+63 ;$ \\
P4 & at $\mathrm{H}+53, \mathrm{H}+55, \mathrm{H}+57, \mathrm{H}+59, \mathrm{H}+61$ dan $\mathrm{H}+63 ;$ \\
P5 & Fungicide and chemical fertilizer every 10 days \\
\hline
\end{tabular}

\section{Plant growth and productivity observation}

Non-destructive observations, were carried out six times starting at day $35^{\text {th }}$ after planting until the research end to measure growth parameters, including plant high, leaves sheet, number of sprouts and blight late disease. Then, the productivity parameter data including diameter, mass and number of the bulbs were collected after harvesting.

\section{Blight late intensity determination}

The blight late disease intensity was observed from the leaves tissues by calculating the percentage of infected tissue rates, to depict $P$. infestans infection. Observations were made every seven days after the $35^{\text {th }}$ day. The scale of damage was determined by referring to the following criteria from Halterman et al., (2008) and Kurniawan et al., (2018) (Table 2). Disease intensity was observed based on late blight attack per plant in one plot and by modifying the disease intensity calculation formula, developed by Kurniawan et al., (2018).

Table 2. Intensity criteria of late blight disease.

\begin{tabular}{ll}
\hline Diseases intensity & Leaves Damage $(\%)$ \\
\hline$>75 \%$ & Severe infection \\
$50<\mathrm{x} \leq 75$ & High-moderate infection \\
$25<\mathrm{x} \leq 50$ & Low-moderate infection \\
$0<\mathrm{x} \leq 25$ & Mild infection \\
0 & No infection \\
\hline
\end{tabular}

\section{Data analysis}

The data were analyzed statistically using the Kolmogorov-Smirnov normality test and the homogeneity test using the Levene's test. All of the data were normally and homogeneously distributed ( $\mathrm{p}$ value > 0.050), then followed using one-way ANOVA and Tukey HSD test,. The statistical test was carried out at the $95 \%$ confidence level and the significance level of 0.050 . All of the analyzes were performed using SPSS 23.

\section{RESULT AND DISCUSSION}

Pakis Village, Magelang District has a suitable temperature and humidity for potato cultivation. During the research process, the temperature fluctuation in the area was relatively small, while the humidity experienced a fairly wide range of daily changes. The average daily temperature in Pakis Village was $22.13 \pm 0.81{ }^{\circ} \mathrm{C}$. It is also used as the basis information to inoculate and culture of Trichoderma sp. The humidity fluctuations were relatively fluctuated during the Trichoderma sp. application, where the average daily humidity reached $66.20 \pm 6.26 \%$.

In contrast to the temperature, the humidity changes in Pakis village tend to be erratic, which indicates low water precipitation in the air. This is because the research process was carried out during the dry season. However, a significant change occurred on $49^{\text {th }}$ day to $50^{\text {th }}$ day, with the depression score reaching $32.86 \%$. However, both temperature and humidity in this range are still acceptable for potato plant to grow (Thornton, 2019).

\section{Trichoderma sp microscopic identification}

The cultured mold samples from the Pest and Disease Observation Laboratory of Kedu, Temanggung District on PDA media showed typical morphological conditions. The morphological characteristics of the isolates that appear on the media, were macroscopically rounded, the surface of the colony was smooth and dark green, the spread of hyphae was fast and evenly distributed, but it was not in a radial pattern but spotted in several places. This is probably due to the overcrowding of the inoculated mold population. The microscopic features clearly show three main forms, including hyphae, conidiophore, and conidia (Figure 2). 

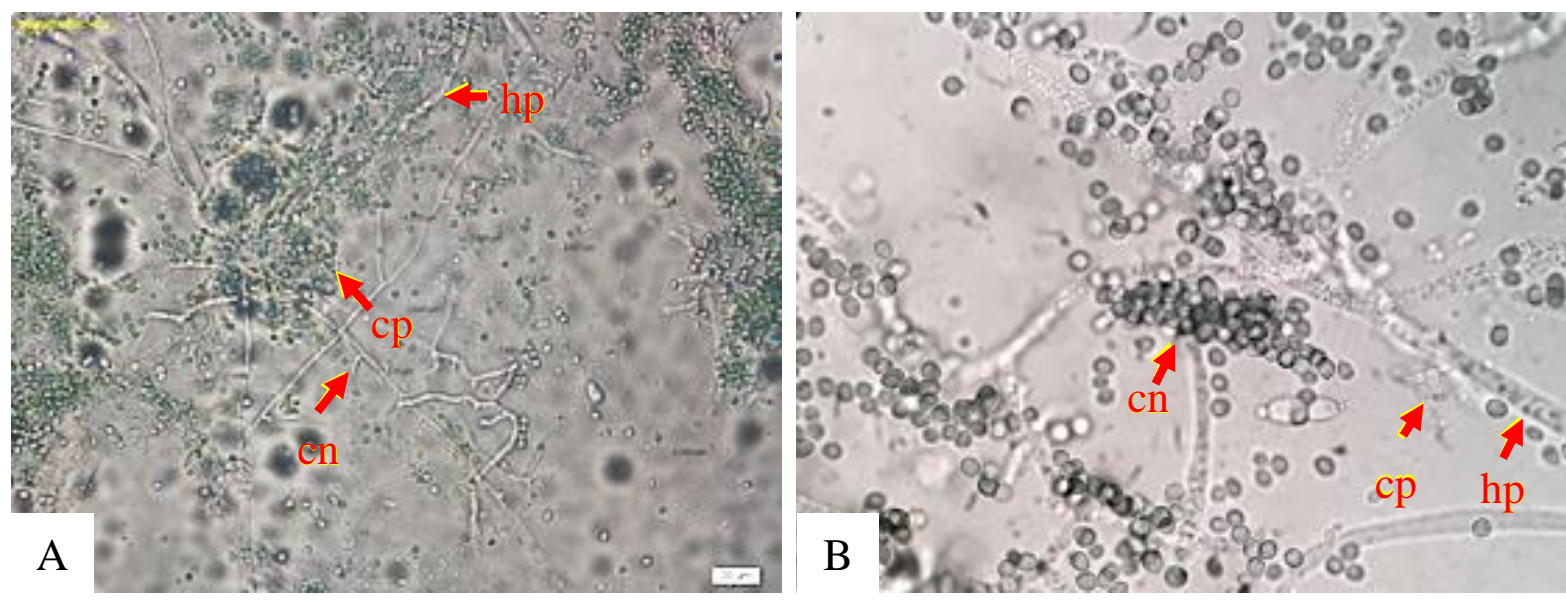

Figure 2. Cultured Trichoderma harzianum from local biocontrol product. A) the colony sample under microscope in 40x of magnification; B) conidia aggregates observed using 100x of magnification. Hp = hypha; $\mathrm{cp}=$ conidiophore $\mathrm{cn}=$ conidia. Scala bar $1: 20 \mu \mathrm{m}$.

The main hyphae that was observed did not show the presence of septa, and the multicellular separation was not clear enough make it looked like a path filled with flowing fluid. However, the bulkhead seen at the hyphae bifurcation forms conidiophores. Furthermore. The conidiophores arising from the main hyphae are short, pyramidal in shape with rounded ends, varying in size between 2.86-11.13 $\mu \mathrm{m}$. The observed conidia were perfectly round, smooth surface without any serrations or indentations, the size was around 2.44-4.64 $\mu \mathrm{m}$. Based on these characteristics, it can be concluded that the isolate used by the Pest and Disease Observation Laboratory of Kedu, was Trichoderma

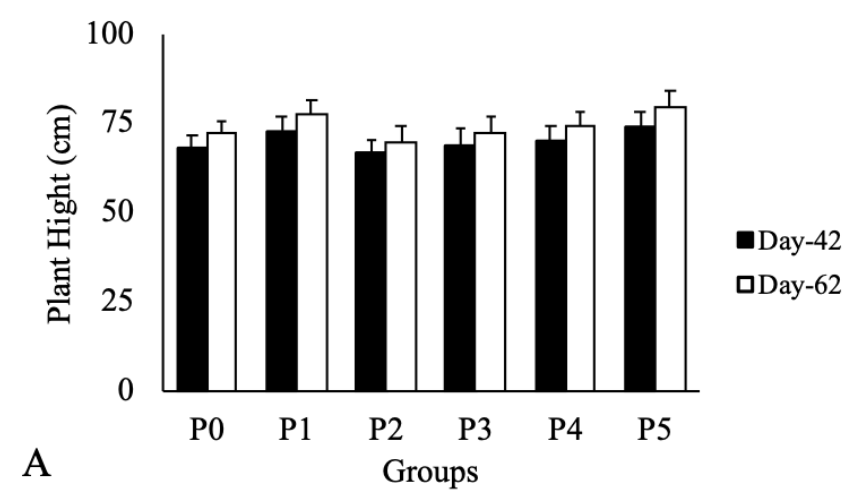

harzianum (Robinson, 2011; Samson et al., 2019; Waghunde et al., 2016).

\section{Growth and productivity of potato plant}

The $T$. harzianum treatment was applied after $42^{\text {nd }}$ day and repeated every 2-3 days (Table 1) for treating late blight in potato plant. The observations was carried out from $42^{\text {nd }}$ day to $65^{\text {th }}$ day indicating that the plants in all plots had no significant difference in height nor number of leaves (Figure 3). It shows that spraying or pouring the $T$. harzianum or chemical fertilizers and pesticides has no significantly different on the growth of potato plants. Even so, there was an increase in plant height by $5-9 \%$ for 2 weeks of treatment.

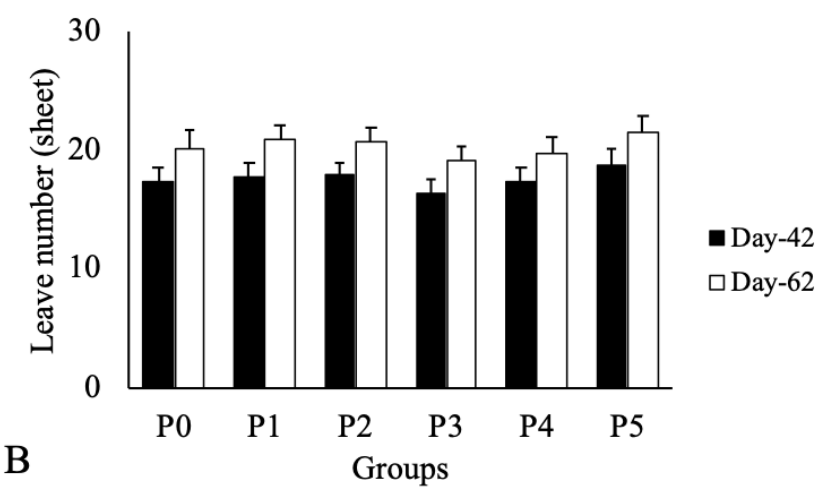

Figure 3. Parameters of potato growth at 42 and 62 days after planting. (A) potato plant height and (B) number of potato leaves in various treatments of $T$. harzianum application.

Various species of Trichoderma are well known able to build up mutualism bond by colonizing plant roots, thereby increases rooting ability (Haryuni, 2015), water and nutrient uptake, resistance to abiotic stress, and increase plant productivity (Zin \& Badaluddin, 2020). However, in this study it was found that the application of $T$. harzianum did not significantly influence differences in the number of leaves of potato plants in the treatment group compared to the control group (Figure 3). This is probably due to the availability of sufficient soil nutrients during the first fertilization was enough to support plant growth very well. The results of this study are in line with the research Soesanto et al., (2020), which stated that $T$. harzianum fertilization has no significant effect on plant growth, but affects plants productivity. 
The application of $T$. harzianum actually has the effect of increasing potato productivity. Potato plants in P4 plot have numerous high quality of tubers, indicates better growth compared to other plots, it also indicated by the high production of large diameter-potato. The application of the T. harzianum was also effectively increasing the production of medium and small potatoes which was higher than the P0 group. Even so, the application by combining spray and poured method, resulted in a better number, size, and weight even than the group treated with chemical fertilizers and pesticides (Table 3 ).

Table 3. Characteristics of tubers per categories

\begin{tabular}{|c|c|c|c|c|c|c|}
\hline \multirow{2}{*}{ Productivity Parameters } & \multicolumn{6}{|c|}{ Treatments } \\
\hline & P0 & P1 & $\mathrm{P} 2$ & $\mathrm{P} 3$ & P4 & P5 \\
\hline \multicolumn{7}{|l|}{ Large-sized bulb } \\
\hline ANTP (Bulb/ plant) & 4.00 & 5.47 & 6.73 & 5.23 & 6.63 & 5.87 \\
\hline LNTP (Bulb) & 8.00 & 11.00 & 14.00 & 11.00 & 15.00 & 14.00 \\
\hline SNTP (Bulb) & 0.00 & 0.00 & 1.00 & 1.00 & 1.00 & 1.00 \\
\hline TNTP (Bulb) & 120.00 & 164.00 & 202.00 & 157.00 & 199.00 & 176.00 \\
\hline $\operatorname{ADTP}(\mathrm{cm})$ & 17.11 & 17.24 & 17.83 & 17.57 & 17.50 & 17.60 \\
\hline LDTP (cm) & 23.00 & 21.00 & 21.00 & 20.00 & 21.00 & 24.00 \\
\hline SDTP $(\mathrm{cm})$ & 13.00 & 13.00 & 14.00 & 14.00 & 14.00 & 12.00 \\
\hline ATWP (gr) & 108.33 & 97.56 & 99.01 & 114.65 & 105.53 & 102.27 \\
\hline ATWT (gr) & 433.33 & 538.13 & 676.23 & 609.58 & 697.09 & 599.30 \\
\hline WLTP (gr) & $1,019.48$ & $1,058.15$ & $1,476.82$ & $1,364.05$ & $1,628.14$ & $1,545.71$ \\
\hline WSTP (gr) & 0.00 & 0.00 & 99.94 & 104.42 & 114.57 & 122.03 \\
\hline TTWP (gr) & $13,000.00^{\mathrm{a}}$ & $16,143.80^{b}$ & $20,286.85^{\mathrm{c}}$ & $18,287.39^{\mathrm{bc}}$ & $20,912.56^{\mathrm{c}}$ & $17,979.08^{b}$ \\
\hline \multicolumn{7}{|l|}{ Medium-sized bulb } \\
\hline ANTP (Bulb/ plant) & 4.37 & 3.27 & 6.73 & 3.87 & 6.63 & 5.87 \\
\hline LNTP (Bulb) & 12.00 & 8.00 & 11.00 & 20.00 & 14.00 & 13.00 \\
\hline SNTP (Bulb) & 0.00 & 1.00 & 1.00 & 1.00 & 1.00 & 1.00 \\
\hline TNTP (Bulb) & 131.00 & 98.00 & 132.00 & 116.00 & 166.00 & 140.00 \\
\hline $\operatorname{ADTP}(\mathrm{cm})$ & 13.00 & 12.81 & 12.64 & 12.46 & 12.40 & 13.08 \\
\hline LDTP (cm) & 15.00 & 14.00 & 15.00 & 14.00 & 15.00 & 15.00 \\
\hline $\operatorname{SDTP}(\mathrm{cm})$ & 11.00 & 10.00 & 11.00 & 10.00 & 10.00 & 11.00 \\
\hline ATWP (gr) & 30.53 & 51.02 & 41.67 & 43.10 & 42.17 & 39.29 \\
\hline ATWT (gr) & 134.76 & 168.11 & 183.17 & 166.34 & 231.70 & 183.42 \\
\hline WLTP (gr) & 370.34 & 446.16 & 405.19 & 829.96 & 574.72 & 491.07 \\
\hline WSTP (gr) & 0.00 & 0.00 & 0.00 & 0.00 & 40.81 & 0.00 \\
\hline TTWP (gr) & $4,042.90^{\mathrm{a}}$ & $5,043.21^{a b}$ & $5,495.12^{\mathrm{b}}$ & $4,990.12^{a b}$ & $6,951.03^{c}$ & $5,502.52^{b}$ \\
\hline \multicolumn{7}{|l|}{ Small-sized bulb } \\
\hline ANTP (Bulb/ plant) & 3.93 & 3.40 & 4.80 & 3.93 & 6.07 & 4.47 \\
\hline LNTP (Bulb) & 10.00 & 10.00 & 22.00 & 13.00 & 21.00 & 13.00 \\
\hline SNTP (Bulb) & 0.00 & 0.00 & 0.00 & 0.00 & 0.00 & 0.00 \\
\hline TNTP (Bulb) & 118.00 & 102.00 & 144.00 & 118.00 & 182.00 & 134.00 \\
\hline ADTP $(\mathrm{cm})$ & 9.36 & 10.00 & 9.52 & 9.62 & 9.32 & 9.57 \\
\hline LDTP (cm) & 10.00 & 11.00 & 11.00 & 11.00 & 12.00 & 12.00 \\
\hline $\operatorname{SDTP}(\mathrm{cm})$ & 8.00 & 8.00 & 7.00 & 8.00 & 8.00 & 8.00 \\
\hline ATWP (gr) & 16.95 & 19.61 & 17.36 & 16.95 & 16.48 & 18.66 \\
\hline ATWT (gr) & 632.59 & 765.71 & 943.18 & 843.08 & $1,029.17$ & 866.28 \\
\hline WLTP (gr) & $1,281.93$ & $1,404.22$ & $1,918.56$ & $1,500.60$ & $2,009.29$ & $2,290.18$ \\
\hline WSTP (gr) & 99.00 & 71.83 & 265.25 & 104.42 & 277.66 & 254.24 \\
\hline TTWP (gr) & $18,977.69^{\mathrm{a}}$ & $22,971.22^{\mathrm{b}}$ & $28,295.35^{\mathrm{c}}$ & $25,292.28^{\mathrm{d}}$ & $30,875.09^{\mathrm{e}}$ & $25,988.28^{d}$ \\
\hline
\end{tabular}

Note: the letter (a-e) indicates significantly different among other plots. ANTP = Average number of tubers per plant; LNTP $=$ The largest number of tubers per plant; SNTP $=$ the smallest number of tubers per plant; TNTP = Total number of tubers per group; ADTP = average diameter per tuber per plant; LDTP = largest tuber diameter; SDTP = smallest tuber diameter per plant; ATWP = Average tuber weight per plant; ATWT = Average tuber $\mathrm{m}$ per plot/treatment; WLTP = weight of the largest tuber in the plot; WSTP = Weight of the smallest tuber in the group; TTWP = total tuber weight per plot. 


\section{Blight late intensity after treatment}

Apart from the growth and productivity, the disease intensity in P1 group was more severe than the other plotts (Table 4). This showed that $T$. harzianum by spraying gives better level of protection than the application of poured $T$. harzianum. The disease intensity was also significantly better than the protection given by chemical fungicides (P5).

T. harzianum is capable of producing auxin-like molecules, which have a positive effect at low concentrations (Napitupulu, 2020). In addition, $T$. harzianum synthesizes the gibberellin which induces potato productivity and may also help root potato plants thus expanding absorption of minerals that aid growth and productivity (Al-Askar et al., 2016; Soesanto et al., 2020). The result of symbiosis between potato plants and $T$. harzianum provides glucose material which is then metabolized to gluconic acid and or fumarate (Bae et al., 2017). The acidic conditions caused by the secretion of the organic acid from $T$. harzianum increase the solubility of cationic minerals in the soil, including $\mathrm{K}$, Mg, Ca, P, Mg, Mn, and Fe. (Naik et al., 2019).

The first $P$ infestans infection was observed at the $42^{\text {nd }}$ day in all plots, except P1-P3. Then, the $T$. harzianum application was significantly reducing the number of leaves damage impacting the disease. Plants on plot P1 were not significantly different from $\mathrm{P} 2$, tended to experience lower late blight (moderate) attacks than other plots (Table 4). In other words, the spraying method can be more effective in reducing the damage caused by blight late disease, rather than poured method.

Table 4. Infection of the blight late in all potato plot after treatment

\begin{tabular}{llll}
\hline Plot & Infection rate (\% leaves/day) & Total levees damage (\%) & Criteria \\
\hline P0 & $3.22 \pm 0.52^{\mathrm{a} \dagger}$ & $81.26 \pm 5.36^{\mathrm{a}}$ & Severe \\
P1 & $1.11 \pm 0.16^{\mathrm{b}}$ & $51.41 \pm 5.08^{\mathrm{b}}$ & Moderate \\
P2 & $1.31 \pm 0.20^{\mathrm{c}}$ & $57.67 \pm 6.00^{\mathrm{b}}$ & Moderate \\
P3 & $3.63 \pm 0.70^{\mathrm{d}}$ & $65.29 \pm 5.56^{\mathrm{c}}$ & High-moderate \\
P4 & $4.00 \pm 0.70^{\mathrm{d}}$ & $67.66 \pm 5.24^{\mathrm{c}}$ & High-moderate \\
P5 & $4.66 \pm 0.75^{\mathrm{d}}$ & $74.12 \pm 4.67^{\mathrm{d}}$ & High-moderate \\
\hline
\end{tabular}

Note: The letter (a-e) indicates significantly difference among plots, analyzed using one-way ANOVA followed with least significant difference (LSD), with significantly level at 95\% or $\alpha=0.05$.

The rate of disease intensity in potato plants given T. harzianum decreased significantly compared to the control group (P0 and P5). Measurements carried out every two days showed that the rate of $P$. infestans infection in all groups increased dramatically, although P0 was significantly the highest followed by

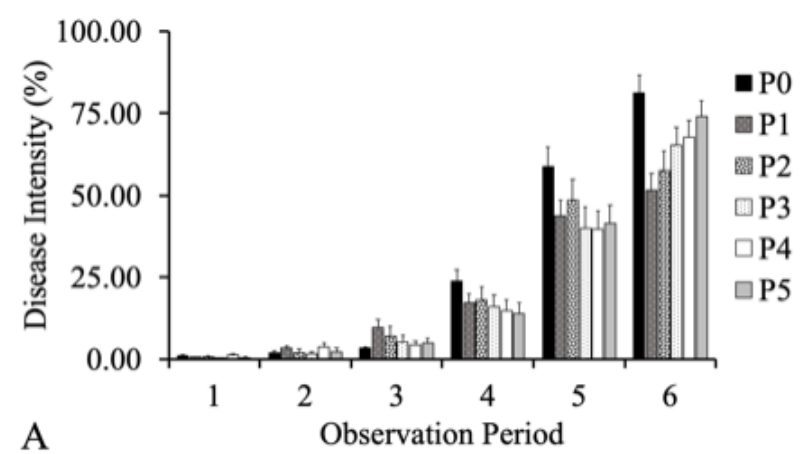

plants in groups P5, P4 and P3, respectively. However, the P0 group experienced a decrease in the rate of infection because most of the tissue was died and the number of the observed plant was also declined (Figure 4).

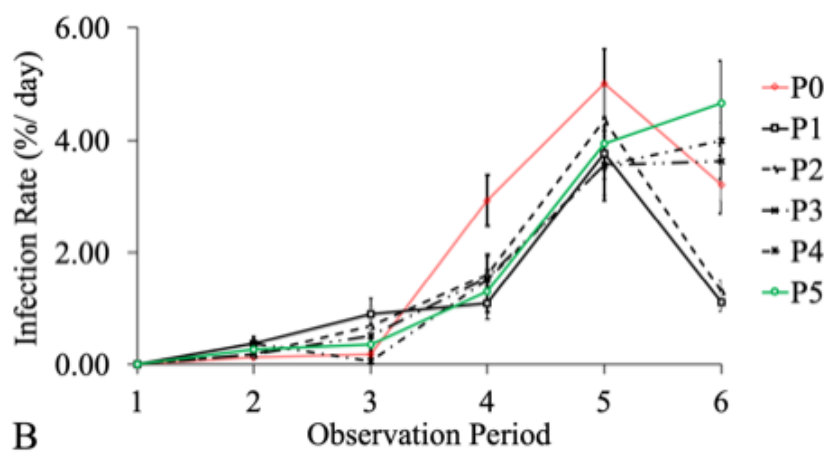

Figure 4. Disease intensity. A) The rate of potato plant disease intensity in various treatments of T. harzianum. B) The infection rate during the potato planting period.

There was less increase in diseases intensity and infection rate in all plots, but increase from the second and third observation period, and drastically increase at the fourth observation period. Significantly, the increases in disease intensity began since the sixth observation, where in the previous observation the disease intensity of the P3-P5 group was lower than that of P1 and P2 (Figure 4). The application of $T$. harzianum as a whole was only sprayed and poured, and was able to slow down the 
disease intensity in the P1-P4 group, even less than the chemical pesticide group.

T. harzianum functions as a biocontrol phytopathogens with several mechanisms, including: 1) being a competitor for pathogenic fungus in the same niche; 2) modification of microhabitat conditions (Adnan et al., 2019); 3) the mechanism of antibiotics by producing enzymes that can degrade pathogenic cell walls (Bae et al., 2017) and 4) mycoparasitism (Naher et al., 2018). T. harzianum mold, possibly producing toxic peptides containing alpha-aminoisobutyric acid (amino acid). These toxic peptides are able to be absorbed into cells and induce the formation of ion channel barrier proteins that prevent $\mathrm{K}^{+}$and $\mathrm{Na}^{+}$from crossing cell membranes (Kai et al., 2018). It makes damage to the action potential of pathogenic cells, and abnormalities in the conductivity and production of cellular respiration energy. In addition, pathogenic stress may also encourage $T$. harzianum, to produce phytohormonelike compounds on a large scale. Like other Trichoderma, T. harzianum also produces antibiotics and cell wall breakdown enzymes such as glucanase, chitinase, and cellulase (Purwantisari et al., 2018a). The T. harzianum has been shown to induce host plants to synthesize more protective enzymes, including peroxidase, chitinase, and glucanase against pathogens (Adnan et al., 2019). Therefore, it can be said that the protection produced by $T$. harzianum is a form of interaction with its host.

This research reveals that local and available materials play a role in eliminating the epidemicplant diseases and effectively improving potato crop quality. This is probably because indigenous fungi are more easily accepted by the cultivated plant in the same area. In addition, this research is an effort to justify scientifically as a foundation for product development and legalization of local products for use on a wider scale, including indigenous Trichoderma-based biofertilizer and biofungicide.

\section{CONCLUSION}

The indigenous Trichoderma used in Pakis village, Magelang district is a species belong to $\mathrm{T}$. harzianum. It is able to be used as biocontrol by delaying late blight diseases infection, and modulate the productivity of potato plants, although it was not effective in increasing height growth and number of leaves. Then, the most effective method to apply indigenous $T$. harzianum as biofungicide and biomodulator is by spraying and pouring a dose of $150 \mathrm{~g} / 10 \mathrm{~L}$ of $T$. harzianum solution. However, we assumed that spraying $100 \mathrm{~g} / 10 \mathrm{~L}$ of $T$. harzianum solution is more effectively used as biocontrol and reducing the number of infections of the late blight.

\section{ACKNOWLEDGEMENT}

Researchers would like to thank the Directorate of Research and Community Service, Deputy for Strengthening Research and Development, Ministry of Research and Technology/ National Republic of Indonesia and Innovation Agency for providing research funding scheme Penelitian Dasar Unggulan Perguruan Tinggi, grant number: 101-20/ UN7.6.1/ PP/ 20, year 2020.

\section{REFERENCES}

Adnan, M., Islam, W., Shabbir, A., Khan, K. A., Ghramh, H. A., Huang, Z., Chen, H. Y. H., \& Lu, G. dong. (2019). Plant defense against fungal pathogens by antagonistic fungi with Trichoderma in focus. Microb. Pathog., 129, 7-18.

Al-Askar, A. A., Ezzat, A. S., Ghoneem, K. M., \& Saber, W. I. A. (2016). Trichoderma harzianum WKY5 and its gibberellic acid control of Rhizoctonia solani, improve sprouting, growth and productivity of potato. Egypt. J. Biol. Pest Control, 26(4), 787-796.

Bae, S. J., Park, Y. H., Bae, H. J., Jeon, J., \& Bae, H. (2017). Molecular identification, enzyme assay, and metabolic profiling of Trichoderma spp. $J$. Microbiol. Biotechnol., 27(6), 1157-1162.

Bairwa, A., Venkatasalam, E. P., Sudha, R., Umamaheswari, R., Sharma, S., \& Singh, B. P. (2016). Management of late blight disease in kharif potato at Karnataka. Potato J., 43(2), 173181.

Beals, K. A. (2019). Potatoes, Nutrition and Health. Am. J. Potato Res., 96(2), 102-110.

BPS, [Badan Pusat Statistik]. (2019a). Luas Panen dan Produksi Kentang 2017-2019. https://jateng. bps.go.id/indicator/55/731/1/luas-panen-danproduksi-kentang.html

BPS, [Badan Pusat Statistik]. (2019b). Produksi Tanaman Sayuran 2019. https://www.bps.go.id/ indicator/55/61/1/produksi-tanaman-sayuran.html

Halterman, D. A., Kramer, L. C., Wielgus, S., \& Jiang, J. (2008). Performance of transgenic potato containing the late blight resistance gene RB. Plant Dis., 92(3), 339-343.

Haryuni. (2015). The Effect of Hot Water Treatment and Dose Trichoderma sp. to Plant Tissue of Seedling Growth from Bud Chips of Sugarcane (Saccharum officinarum). Biosaintifika J. Biol. Biol. Educ., 7(1), 29-36.

Hasenbein, S., Lawler, S. P., Geist, J., \& Connon, R. E. (2016). A long-term assessment of pesticide mixture effects on aquatic invertebrate communities. Environ. Toxicol. Chem., 35(1), 218-232. 
Kai, K., Mine, K., Akiyama, K., Ohki, S., \& Hayashi, H. (2018). Anti-plant viral activity of peptaibols, trichorzins HA II, HA V, and HA VI, isolated from Trichoderma harzianum HK-61. J. Pestic. Sci., 43(4), 283-286.

Kholifah, E., \& Mustanir, A. (2019). Food Policy and Its Impact on Local Food. J. Asian Rev. Public Aff. Policy, 4(3), 1-15.

Kim, K. H., Kabir, E., \& Jahan, S. A. (2017). Exposure to pesticides and the associated human health effects. Sci. Total Environ., 575, 525-535.

Kurniawan, H., Sulastrini, I., \& Suganda, T. (2018). Uji Ketahanan Klon Kentang Hasil Pesilangan Atlantic x Repita terhadap Penyakit Hawar Daun Phytophthora infestans. Agrikultura, 29(2), 100.

Leesutthiphonchai, W., Vu, A. L., Ah-Fong, A. M. V., \& Judelson, H. S. (2018). How does phytophthora infestans evade control efforts? Modern insight into the late blight disease. Phytopathology, 108(8), 916-924.

Mahmood, I., Imadi, S. R., Shazadi, K., Gul, A., \& Hakeem, K. R. (2016). Effects of Pesticides on Environment. In S. I. P. Switzerland (Ed.), Plant, Soil and Microbes: Implications in Crop Science.

Majeed, A., Muhammad, Z., Ullah, Z., Ullah, R., \& Ahmad, H. (2017). Late blight of potato (Phytophthora infestans) I: fungicides application and associated challenges. Turkish J. Agric. Food Sci. Technol., 5(3), 261.

Naher, L., Yusuf, U. K., Habib, S. H., Huynh, K. Y., \& Siddiquee, S. (2018). Mycoparasitism activity of trichoderma harzianum associated with chitinase expression against Ganoderma boninense. Pakistan J. Bot., 50(3), 1241-1245.

Naik, K., Mishra, S., Srichandan, H., Singh, P. K., \& Sarangi, P. K. (2019). Plant growth promoting microbes: Potential link to sustainable agriculture and environment. Biocatal. Agric. Biotechnol., 21(July), 101326.

Napitupulu, T. P. (2020). Evaluation of antifusarium and auxin production of Trichoderma virens InaCC F1030 isolated from rhizosphere of banana. J. Microb. Syst. Biotechnol., 2(1), 31-39. https://doi.org/10.37604/jmsb.v2i1.39

Purwantisari, S., Priyatmojo, A., Sancayaningsih, R. P., Kasiamdari, R. S., \& Budihardjo, K. (2018a). Systemic inducing resistance against late blight by applying antagonist Trichoderma Viride. J. Phys. Conf. Ser., 1025(1).

Purwantisari, S., Priyatmojo, A., Sancayaningsih, R. P., Kasiamdari, R. S., \& Budihardjo, K. (2018b).
The resistance of potatoes by application of Trichoderma viride antagonists fungus. E3S Web Conf., 73(July 2013).

Rachman, T., \& Napitupulu, D. (2018). User acceptance analysis of potato expert system application based on TAM approach. Int. J. Adv. Sci. Eng. Inf. Technol., 8(1), 185-191.

Robinson, M. (2011). Pictorial atlas of soil and seed fungi: morphologies of cultured fungi and key to species. Ref. Rev., 25(4), 43-44.

Samson, R. A., Houbraken, J., Thrane, U., \& Frisvad, J. C. (2019). Food and indoor fungi. Westerdijk Fungal Biodiversity Institute: The Netherlands.

Schepers, H., Gunadi, N., Putter, H. De, Moekasan, T. K., Prabaningrum, L., \& Karjadi, A. K. (2016). Results of potato late blight demonstrations in Pangalengan, Indonesia November 2015February 2016. Wageningen Universsity Research: The Netherland.

Soesanto, L., Ilahiyyah, H., Mugiastuti, E., Manan, A., \& Rostaman, R. (2020). Raw secondary metabolites of Trichoderma harzianum T10 in tapioca flour towards cucumber damping-off. Biosaintifika J. Biol. Biol. Educ., 12(2), 226-234.

Subhani, M. N. (2016). Phytophthora infestans (Mont.) de Bary (Peronosporales : Pythiaceae): a review of life history, evolutionary status of pathogen, host range, mating types, symptomology, disease cycle, means of dispersal, extent of losses, and management. J. Glob. Agric. Ecol., 5(2), 108-126.

Thornton, M. (2019). Potato growth and development. In J. C. Stark., P. Nolte., and M. Thornton. Potato production systems (pp. 111154). Springer Nature: Switzerland.

Waghunde, R. R., Rahul, M. S., \& Ambalal, N. S. (2016). Trichoderma: A significant fungus for agriculture and environment. African J. Agric. Res., 11(22), 1952-1965.

Zin, N. A., \& Badaluddin, N. A. (2020). Biological functions of Trichoderma spp. for agriculture applications. Ann. Agric. Sci., 65(2), 168-178.

Zubrod, J. P., Englert, D., Wolfram, J., Rosenfeldt, R. R., Feckler, A., Bundschuh, R., Seitz, F., Konschak, M., Baudy, P., Lüderwald, S., Fink, P., Lorke, A., Schulz, R., \& Bundschuh, M. (2017). Long-term effects of fungicides on leaf-associated microorganisms and shredder populations - an artificial stream study. Environ. Toxicol. Chem., 36(8), 2178-2189. 